\title{
LITERASI MEDIA DIGITAL BERBASIS INDIVIDUAL COMPETENCE FRAMEWORK PADA KELUARGA BURUH MIGRAN ANGGOTA PAGUYUBAN SERUNI KABUPATEN BANYUMAS
}

\author{
Mite Setiansah, Wiwik Novianti, S. Bekti Istiyanto \\ Universitas Jenderal Soedirman Purwokerto \\ mite.setiansah@unsoed.ac.id
}

\begin{abstract}
ABSTRAK
Media digital berbasis internet saat ini sudah menjadi bagian tidak terpisahkan dalam kehidupan masyarakat termasuk buruh migran dan keluarganya. Di sisi lain, ada permasalahan yang tidak kalah penting untuk diperhatikan. Keterampilan teknis (technical competencies) buruh migran dan keluarganya dalam menggunakan media digital belum diiringi dengan keterampilan untuk mengkritisi (critical competencies) di dalam mengakses media. Pada tataran inilah, pemberian pendidikan literasi media digital berbasis individual competency framework menjadi penting bagi mereka. Pelatihan literasi media digital diberikan kepada Anggota Paguyuban Peduli Buruh Migran dan Perempuan "Seruni" Kabupaten Banyumas dengan pertimbangan bahwa paguyuban tersebut telah terbiasa melakukan kegiatan advokasi dan pemberdayaan perempuan dan buruh migran, sehingga diharapkan ipteks yang diterapkan tidak hanya berhenti di kelompok khalayak sasaran namun juga dapat disebarluaskan kepada kelompok masyarakat lainnya. Kegiatan pengabdian ini dilaksanakan dalam bentuk pelatihan. Capaian keberhasilan dilakukan dengan pengukuran tingkat literasi media melalui pretest dan post test. Berdasarkan hasil evaluasi kegiatan, maka dapat dikatakan program pengabdian telah mencapai tingkat keberhasilan $100 \%$ dari sisi penyampaian materi kegiatan dan jadwal pelaksanaan. Kegiatan ini juga telah berhasil meningkatkan kompetensi literasi digital kelompok sasaran. Berdasarkan hasil pre-test diketahui bahwa $67 \%$ peserta memiliki tingkat literasi di level basic, 20\% médium, dan $13 \%$ advance. Setelah diberikan pelatihan dan diukur kembali melalui post test, diperoleh perubahan komposisi, dimana peserta dengan tingkat literasi di level basic berkurang menjadi $40 \%$, di level médium meningkat menjadi 33\% dan di level advance menjadi $27 \%$.
\end{abstract}

Kata Kunci: Buruh Migran, Media Digital, Literasi Media, Individual Competencies Framework

\section{PENDAHULUAN}

Berdasarkan data BNP2TKI 31 Januari 2018, jumlah buruh atau buruh migran Indonesia mengalami kenaikan sebanyak 4.176 orang. Pada 31 Januari 2016 jumlah buruh migran Indonesia adalah 23.665 orang dan menurun pada 31 Januari 2017 menjadi 17.001 orang. Namun, pada 31 Januari 2018 jumlah buruh migran Indonesia kembali naik 
menjadi 21.177 orang. Kenaikan terbanyak terjadi pada buruh migran Indonesia berjenis kelamin perempuan, yaitu naik 2. 598 orang dibandingkan buruh migran Indonesia lakilaki yang naik 1.578 orang.

Jika diuraikan lebih rinci berdasarkan propinsi maka Provinsi Jawa Tengah menempati peringkat kedua pemasok buruh migran Indonesia telah Jawa Barat. Hingga 31 Januari 2018 buruh migran asal propinsi Jawa Tengah mencapai 3.891 orang.

Tabel 1. Jumlah buruh migran Indonesia (5 provinsi tertinggi)

\begin{tabular}{|l|l|l|l|l|l|}
\hline No & PROVINSI & $\begin{array}{l}\text { Januari } \\
2016\end{array}$ & $\begin{array}{l}\text { Januari } \\
2017\end{array}$ & $\begin{array}{l}\text { Januar } \\
\text { i } 2018\end{array}$ & Jumlah \\
\hline 1 & JAWA BARAT & 5.308 & 3.581 & 4.526 & 945 Naik \\
\hline 2 & JAWA TENGAH & 5.225 & 4.026 & 3.891 & 135 Turun \\
\hline 3 & JAWA TIMUR & 4.432 & 3.569 & 3.857 & 288 Naik \\
\hline 4 & NUSA TENGGARA BARAT & 3.912 & 2.230 & 3.637 & 1.407 Naik \\
\hline 5 & LAMPUNG & 1.692 & 1.179 & 1.343 & 164 Naik \\
\hline
\end{tabular}

Sumber: www.bnp2tki.go.id/uploads/data/data_13-022018_020246_Laporan_Pengolahan_Data_BNP2TKI_2018_-_januari_1.pdf diakses 18 Februari 2018

Berdasarkan tabel 1 di atas maka tampak bahwa jumlah buruh migran Indonesia asal Jawa Tengah mengalami penurunan pada Januari 2018. Namun demikian, meskipun mengalami penurunan, Provinsi Jawa Tengah masih menempati posisi kedua teratas. Selanjutnya bila dilihat berdasarkan kota yang menjadi pengirim buruh migran terbanyak secara nasional, Kabupaten Banyumas berada di urutan ke-17 di antara kota yang menjadi penyedia dan pengirim buruh migran terbanyak di Indonesia, yaitu 258 orang. Sementara peringkat teratas adalah Indramayu yang memiliki buruh migran 1.629 orang hingga 31 Januari 2018.

Bagi Kabupaten Banyumas sendiri, meskipun masih termasuk 20 besar kota dengan jumlah buruh migran terbanyak, jumlah buruh migran selama 3 tahun terakhir selalu mengalami penurunan. Pada Januari 2016 jumlah buruh migran Indonesia asal 
Banyumas adalah 340 orang, menurun pada Januari 2017 menjadi 279, dan turun lagi pada Januari 2018 menjadi 258 orang.

Meskipun telah terjadi penurunan, permasalahan buruh migran ini tetap perlu menjadi perhatian. Data BNP2TKI Januari 2018 yang menyebutkan bahwa 50\% buruh migran berstatus kawin sehingga harus menjalani kehidupan keluarga secara terpisah telah menghadirkan permasalahan tersendiri. Proses komunikasi antar anggota yang terputus, kondisi anak yang kurang mendapat perhatian karena ditinggal bekerja ibunya, hingga pasangan yang kemudian menjalin hubungan lain adalah beberapa permasalahan yang melingkupi kehidupan keluarga buruh migran.

Di tengah permasalahan komunikasi yang dihadapi keluarga buruh migran, media digital berbasis internet kemudian hadir sebagai solusi. Dengan cepat piranti digital seperti smartphone, tablet, hingga laptop menjadi barang yang akrab dengan kehidupan mereka. Dengan remiten ekonomi yang diperoleh buruh migran selama bekerja di luar negeri, membeli smartphone bukanlah sesuatu yang sulit apalagi ketika perangkat tersebut dipandang 19ias menjadi solusi bagi permasalahan komunikasi mereka. Dengan smartphone mereka lebih mudah terhubung dengan anggota keluarga, dapat memberikan hiburan dan alat bantu belajar untuk anak yang ditinggalkan, dan lebih mudah terhubung dengan suami atau istri. Mereka kini terbiasa berkomunikasi melalui whatsapp, facebook, skype, Instagram. Anak-anak juga dapat mengakses dan mencari informasi apapun melalui beragam browser dan search engine yang tersedia.

Dalam konteks di atas, kehadiran media digital di tengah keluarga buruh migran memang layak untuk dirayakan. Media digital telah media komunikasi, hiburan bahkan media advokasi dan pemberdayaan bagi mereka. Sebagaimana disebutkan dalam penelitian Sri Wijayanti dan Nurul Azizah Zayzda (2016) berjudul Transnational Migrant Workers' Life: Paguyuban Seruni's Strategy to Solve Migrant Workers' 
Problems Overseas by Using Online Media. Penelitian tersebut menyimpulkan bahwa kehadiran teknologi informasi telah melahirkan sebuah komunitas baru disebut digital diaspora, dimana para buruh migran telah menggunakan teknologi informasi digital untuk memenuhi kebutuhan dan kepentingan mereka, memperoleh solusi bagi permasalahan mereka dan juga menjadi solusi bagi keluarga yang mereka tinggalkan.

Di sisi lain, muncul pertanyaan baru, ketika para buruh migran dan keluarga sudah memiliki keterampilan teknis (technical skill) yang memadai dalam mengakses dan menggunakan media digital, apakah mereka juga memiliki critical skill yang memadai untuk bisa melakukan analisis, mengevaluasi, menilai informasi yang diperoleh dari media sosial itu. Apalagi dengan maraknya fenomena hoax saat ini. Apakah para buruh migran juga menyadari adanya resiko dan bahaya online di media digital, bukan hanya saat mereka mengkonsumsi atau diterpa informasi melainkan juga saat mereka memproduksi isi media? Anak-anak buruh migran yang ditinggalkan di rumah dan hanya berteman media digital juga sangat rentan untuk diterpa konten pornografi bahkan tidak jarang juga tanpa disadari telah menjadi produsen konten pornografi.

Kehadiran media digital yang memungkinkan penggunanya untuk juga memproduksi isi, melalui kiriman foto, gambar, tulisan, video telah menghadirkan budaya baru. Kebiasaan selfie, memotret makanan, berkomentar, curhat, membuat video blog telah menjadi sebuah kelaziman yang dilakukan banyak orang saat ini, termasuk buruh migran dan keluarganya. Di situlah peluang untuk menimbulkan permasalahan seperti hate speech, kasus ITE, hingga hilangnya batas ruang public dan privat menjadi terbuka lebar.

Berdasarkan wawancara dengan pengurus Paguyuban Seruni, diakui bahwa mereka telah sering mendapat pelatihan teknis, seperti bagaimana membuat web dan sebagainya, namun belum pernah mendapat pelatihan literasi media digital khususnya 
yang mengasah kompetensi kritis dan social mereka. Penelitian terdahulu berjudul Pengembangan Model Ketahanan Keluarga Terhadap Dampak Media Melalui Pemberdayaan PKK sebagai Agen Media Literacy yang dilakukan pada tahun 2013 dan 2014 juga mengungkap fakta bahwa internet telah menjadi salah satu rujukan informasi dalam keluarga. Namun penelitian tersebut juga mengungkapkan bahwa sebagian besar kader PKK yang menjadi informan mengakui mengalami ketertinggalan kemampuan (skill) di dalam mengakses dan mengoperasikan media berbasis online dibanding anakanak mereka (Setiansah, 2014). Dalam penelitian lain, yang berjudul Pemaknaan Smartphone oleh Perempuan Urban: Interseksi Gender, Kelas dan Agama (Setiansah, 2015), terungkap bahwa sebagian besar perempuan informan yang juga sekaligus adalah ibu, mengaku menjadikan smartphone sebagai bagian yang tidak terpisahkan dalam keseharian mereka. Benang merah dari kedua penelitian ini adalah bahwa meskipun keterampilan perempuan dan orangtua terbatas, tingkat penggunaan media online khususnya melalui smartphone sudah cukup tinggi. Pada tataran ini pemberian pelatihan literasi media digital menjadi penting, dengan harapan pengguna media digital dapat memiliki kompetensi teknis maupun kritis di dalam mengakses dan menggunakan media online. Kegiatan ini dilakukan dengan tujuan untuk membangun dan meningkatkan taraf literasi media digital khususnya pada buruh migran dan keluarganya.

\section{METODE PENGABDIAN}

Kegiatan ini dilaksanakan dalam bentuk penyuluhan dan pelatihan literasi media digital yang mencakup sejumlah materi sebagai berikut:

Tabel 2. Materi Pelatihan

\begin{tabular}{|c|l|l|l|}
\hline No & \multicolumn{1}{|c|}{ Materi } & Metode Pembelajaran & \multicolumn{1}{c|}{ Capaian Belajar } \\
\hline 1 & $\begin{array}{l}\text { Resiko dan } \\
\text { bahaya Online }\end{array}$ & $\begin{array}{l}\text { Penyuluhan dan Diskusi } \\
\text { Interaktif }\end{array}$ & $\begin{array}{l}\text { Peserta mampu menjelaskan } \\
\text { jenis resiko dan bahaya online }\end{array}$ \\
\hline 2 & $\begin{array}{l}\text { Urgensi dan } \\
\text { Kompetensi }\end{array}$ & $\begin{array}{l}\text { Penyuluhan dan diskusi } \\
\text { interaktif }\end{array}$ & $\begin{array}{l}\text { Peserta mampu menjelaskan } \\
\text { urgensi dan kompetensi yang }\end{array}$ \\
\hline
\end{tabular}




\begin{tabular}{|c|l|l|l|}
\hline & Literasi Digital & $\begin{array}{l}\text { harus dimiliki agar melek } \\
\text { media digital }\end{array}$ \\
\hline 3 & $\begin{array}{l}\text { Keterampilan } \\
\text { mengakses dan } \\
\text { melindungi diri } \\
\text { dari konten tidak } \\
\text { diinginkan di } \\
\text { media sosial }\end{array}$ & $\begin{array}{l}\text { Praktek mengakses dan } \\
\text { menggunakan fitur-fitur } \\
\text { pelaporan, safe search, } \\
\text { blokir dll di media sosial } \\
\text { (WhatApps dan } \\
\text { Facebook) }\end{array}$ & $\begin{array}{l}\text { Peserta mampu mengakses, } \\
\text { melakukan download } \\
\text { aplikasi, menggunakan fitur } \\
\text { pelaporan, blokir, safe search, } \\
\text { dll. }\end{array}$ \\
\hline 4 & $\begin{array}{l}\text { Aspek etis dan } \\
\text { hukum di media } \\
\text { online }\end{array}$ & $\begin{array}{l}\text { Penyuluhan dan diskusi } \\
\text { interaktif }\end{array}$ & $\begin{array}{l}\text { Peserta mampu menjelaskan } \\
\text { permasalahan etis dan hukum } \\
\text { (ITE) }\end{array}$ \\
\hline 5 & $\begin{array}{l}\text { Keterampilan } \\
\text { memproduksi } \\
\text { konten media } \\
\text { digital }\end{array}$ & $\begin{array}{l}\text { Praktek memproduksi } \\
\text { konten berupa produksi } \\
\text { video dan upload video } \\
\text { di youtube }\end{array}$ & $\begin{array}{l}\text { Peserta mampu memproduksi } \\
\text { konten positif dan } \\
\text { mengunggahnya ke Youtube }\end{array}$ \\
\hline
\end{tabular}

Evaluasi dilakukan melalui pemberikan pre-test dan post-test dalam bentuk kuesioner kepada peserta, sebelum dan sesudah kegiatan pelatihan dilaksanakan. Indikator pencapaian tujuan akan dibagi ke dalam dua aspek, yaitu pelaksanaan program dan hasil belajar. Analisis data dilakukan dengan menggunakan teknik analisis data deskriptif, dimana terhadap data kualitatif dilakukan kategorisasi sementara terhadap data kuantitatif dianalisis dengan tabulasi, pembuatan prosentase dan disajikan dalam grafik atau tabel.

\section{HASIL DAN PEMBAHASAN}

\section{Hasil Pengujian Capaian Belajar: Pretest dan Posttest}

Untuk megukur capaian hasil belajar peserta maka diberikan pre-test dan posttest yang memuat sejumlah pertanyaan dengan menggunakan pendekatan individual competence framework (ICF). Pendekatan itu dipilih dengan pertimbangan bahwa pendekatan tersebut memiliki indikator literasi yang cukup lengkap, mulai dari technical competence, critical competence, hingga social competence.

Hasil dari pengukuran pre-test dengan perhitungan interval berikut: 


$$
\begin{array}{ll}
\text { Interval }=\left(\frac{X t-X r}{3}\right)+1 & \begin{array}{l}
\text { Keterangani } \\
X t-\text { Nilai maksimum } \\
\\
191-114
\end{array}
\end{array}
$$

Menghasilkan kategorisasi tingkat literasi media sebagai berikut:

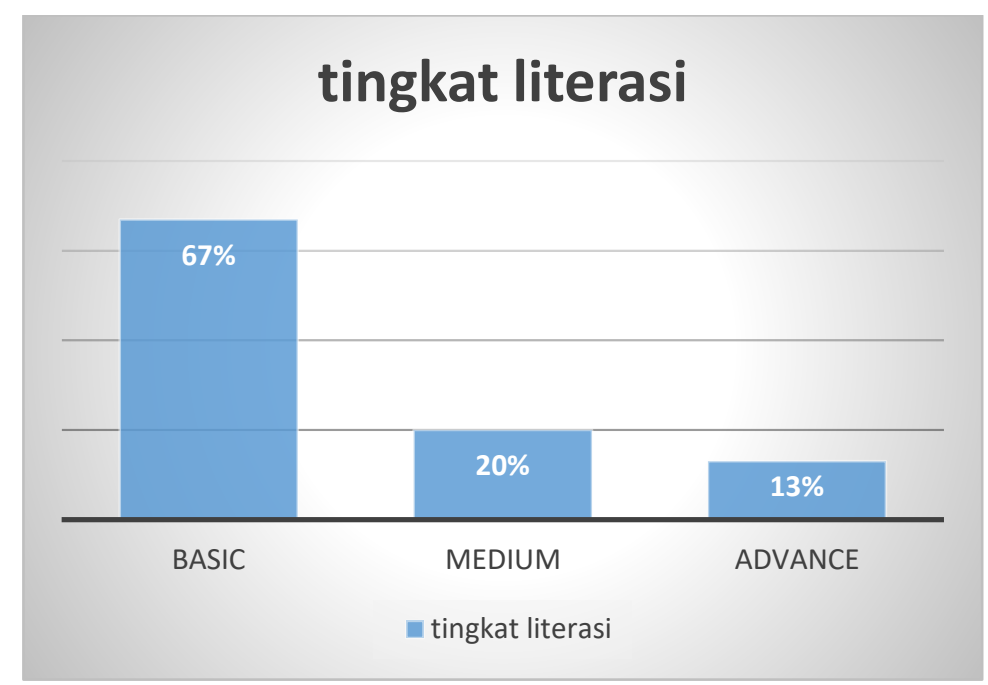

Sementara pengukuran post test dilakukan dengan perhitungan interval berikut:

$$
\begin{aligned}
\text { Interval } & =\left(\frac{X t-X r}{3}\right)+1 \\
& =\frac{198-112}{3}+1 \\
& =30
\end{aligned}
$$

Hasil perhitungannya adalah sebagai berikut: 


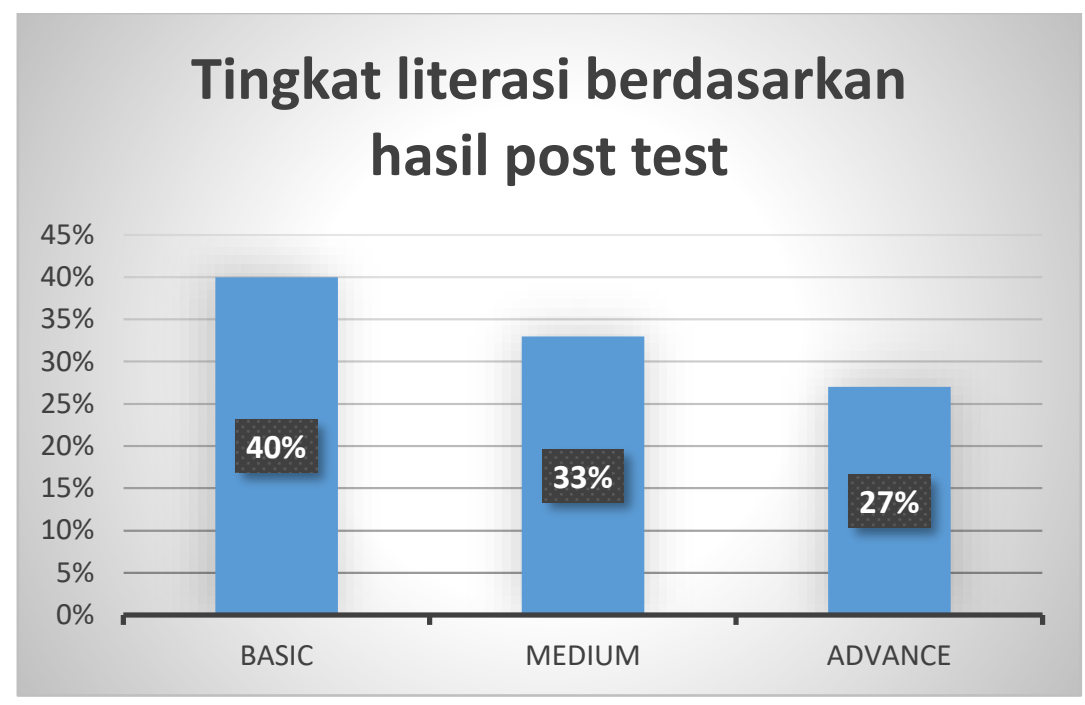

\section{Pembahasan}

Berdasarkan hasil pre test dan post test, diketahui bahwa sebagian besar tingkat literasi media digital anggota Paguyuban Seruni masih termasuk dalam kategori basic. Unit literasi media pada European Directorate General Information Society and Media mengatakan bahwa individu yang masih berada level basic ditandai dengan kepemilikan keterampilan dasar di dalam menggunakan media. Pengguna media memahami fungsifungsi dasar dari media yang digunakannya, namun belum memiliki keterampilan lebih jauh untuk secara maksimal memanfaatkan semua fitur yang tersedia.

"The individual has a set of abilities that allows basic use of the media. There is a limited use of media. The user knows its basic function, deciphers its basic codes and uses it for specific ends and to determine the tool. The user's capacity to critically analyze the information received is limited. Its communicative capability through media is also limited." (dalam Kurniawati dan Baroroh, 2016).

Berdasarkan hasil observasi selama program pengabdian berlangsung, terungkap bahwa sebagian besar peserta memang mengakui dan tampak telah cukup familiar di dalam menggunakan media digital berbasis internet khususnya berupa smartphone. Berdasarkan kategori kompetensi yang dimiliki maka dapat dikatakan sebagian besar baru memilliki kompetensi yang memadai dalam aspek technical skill saja atau use skill. Hasil perhitungan pretest, pada aspek technical skill ini, peserta memiliki rata-rata skor 
57,3. Pada level tersebut, peserta mampu menggunakan media, mengenal berbagai aplikasi media sosial, dapat berkirim pesan dan melakukan panggilan melalui media sosial di smartphone. Sebagian peserta juga menyatakan sering menggunakan media internet untuk mencari informasi seperti resep masakan. Mereka juga dapat berkirim gambar atau foto melalui Whatsapp dan Facebook. Sebagian dari peserta juga telah terbiasa berkirim email menggunakan komputer atau laptop. Setelah pelatihan diberikan, skor keterampilan teknis ini meningkat menjadi 61,46. Peningkatan skor ini juga ditunjukkan dengan kemampuan teknis peserta yang bertambah yaitu dengan keterampilan untuk menggunakan fitur-fitur pengamanan di media sosial dan smartphone yang mereka miliki. Peserta mampu mengaktifkan safe search di google, mengetahui dan mampu menggunakan fitur pelaporan maupun blokir di Facebook, Whatsapp dan Youtube.

Pendekatan individual competence framework mengelompokan keterampilan bermedia menjadi dua kategori kompetensi yaitu personal competence dan social competence. Termasuk dalam kategori personal adalah technical skill dan critical skill. Mencermati keterampilan yang dimiliki oleh peserta pelatihan yang masih lebih pada level technical skill maka dapat dikatakan bahwa kompetensi literasi yang dimiliki masih pada level personal, sekedar mampu untuk dirinya sendiri. Jika dilihat dari aspek critical skill yaitu kompetensi kognitif untuk memahami makna dan informasi yang diterima melalui media internet, maka berdasarkan hasil perhitungan pretest diperoleh skor ratarata 56,3 dan meningkat menjadi 60,26 setelah pelatihan. Pada aspek critical skill ini peserta diberikan pelatihan tentang resiko dan bahaya online, aspek etik dan hukum di media sosial dan di internet.

Meski pada aspek personal competence sudah menunjukkan level literasi yang cukup memadai, namun jika dilihat pada aspek social competence maka diketahui bahwa 
anggota paguyuban Seruni sebagai peserta kegiatan pelatihan masih memiliki tingkat literasi yang rendah. Social competence menuntut pengguna media untuk juga memiliki tingkat literasi tidak hanya sebagai konsumen melainkan juga sebagai produser. Pada tataran ini, literasi tidak cukup hanya untuk diri sendiri seperti pada technical skill dan critical skill namun juga harus mampu menggunakannya media untuk berkontribusi atau berpartisipasi dalam masyarakat (communicative abilities). Pengguna media digital dikatakan melek media jika dia memiliki kemampuan untuk berpartisipasi di masyarakat melalui produksi konten, baik berupa artikel di web, blog maupun video blog atau di youtube. Berdasarkan hasil pre-test, diketahui bahwa skor rata-rata untuk social competence ini cukup rendah yaitu 28,26 dan meningkat menjadi 32,4. Peningkatan keterampilan tersebut diperoleh melalui pelatihan produksi konten video blog, mulai dari pengambilan video hingga posting/ unggah ke youtube.

Keterampilan produksi konten menjadi pembeda antara kompetensi yang dibutuhkan untuk literasi media dengan literas media internet. Pada era literasi media konvensional literasi media hanya menuntut keterampilan mengakses dan memahami media sebagaimana dikatakan Potter dalam bukunya yang berjudul "Media Literacy" (2005:34) bahwa media literacy adalah sebuah perspekif yang digunakan secara aktif ketika individu mengakses media dengan tujuan untuk memaknai pesan yang disampaikan oleh media. Sementara di era digital, literasi membutuhkan keterampilan khusus yang lebih dari sekedar kompetensi literasi media sebelumnya. Secara khusus Livingstone (2008: 106) mengatakan bahwa,

Internet literacy in particular may be distinguished from other forms of literacy to the extent that people specific skills, experiences, texts, institutions and cultural values associated with the internet differ from those associated with print, audiovisual, or other forms communication.

Dengan demikian, program pengabdian masyarakat ini telah memberikan keterampilan literasi yang berupaya memenuhi kebutuhan pengguna media di era digital. 


\section{KESIMPULAN}

1. Anggota paguyuban Seruni yang menjadi peserta program pada umumnya memiliki personal competence yang memadai dengan perolehan skor rata-rata di atas 60 untuk technical skill dan critical skill. Namun mereka masih memiliki social competence yang rendah dengan rata-rata skor di bawah 50 sehingga secara keseluruhan tingkat literasi peserta berada dalam kategori level basic.

2. Pemberian pelatihan literasi media khususnya media digital menjadi penting mengingat teknologi digital sudah sangat lekat dengan kehidupan sehari-hari masyarakat termasuk para buruh migran dan keluarganya. Pendidikan literasi media efektif di dalam meningkatkan kompetensi literasi peserta pelatihan yang ditunjukkan dari peningkatan hasil belajar yang diukur melalui post-test. Hasil post test menunjukkan penurunan prosentasi peserta yang berada di level basic dan peningkatan prosentase peserta yang memiliki tingkat literasi di level advance dan medium.

\section{DAFTAR PUSTAKA}

Kurniawati, Juliana dan Baroroh, Siti. 2016. "Literasi Media Digital Mahasiswa Universitas Muhammadiyah Bengkulu". Jurnal Komunikator. Vol. 8 No. 2 November 2016. Hal. 51-66

Livingstone, S. 2013. "Online Risk, Harm and Vulnerability: Reflections on the Evidence Base for Child Internet Safety Policy” dalam ZER Vol. 18. No. 35. Hal. 13-28. ISSN: 1137-1102

Setiansah, M. 2015. "Pemaknaan Samrtphone oleh Perempuan Urban: Interseksi Gender, Kelas dan Agama" Disertasi. Tidak diterbitkan. Yogyakarta: Sekolah Pascasarjana UGM

Setiansah, M. Prastyanti, S. dan Pangestuti, S. 2013. "Pengembangan Model Ketahanan Sosial Masyarakat Terhadap Dampak Media Massa Melalui Pemberdayaan PKK sebagai Agen Media Literacy di Kabupaten Banyumas" Jurnal Acta Diurna. Vol. 9 No 2. 2013

Wijayanti, Sri dan Zazyda, Azizah N. 2016. "Transnational Migrant Workers' Life: Paguyuban Seruni's Strategy to Solve Migrant" Workers' Problems Overseas by 
Using Online Media. Prosiding Innovation in Regional Public Service for Sustainability

www.bnp2tki.go.id/uploads/data/data_13-02-

2018_020246_Laporan_Pengolahan_Data_BNP2TKI_2018_-_januari_1.pdf diakses 18

Februari 2018 